Ks. Bogdan Czyżewski

UAM, Poznań

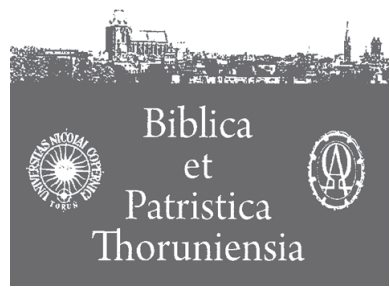

$2(2009)$

\title{
Orygenesowe elementy egzegezy i nauki w komentarzu Do Księgi Jonasza św. Hieronima
}

Manilo Simonetti w znanym opracowaniu dotyczącym historii egzegezy patrystycznej: Między dosłownościa a alegorią, napisał w odniesieniu do św. Hieronima, że jego „publiczne oderwanie się od Orygenesa teologa nie pociągnęło za sobą, $\mathrm{w}$ tym ważnym momencie sporu, znacznych zmian $\mathrm{w}$ ratio interpretandi $[\ldots]$ w porównaniu z czasem poprzedzającym spór"1. Tego rodzaju stwierdzenie może budzić pewne wątpliwości, zwłaszcza kiedy weźmiemy pod uwagę fakt, że Hieronim chciał całkowicie zerwać z metodą egzegetyczną Aleksandryjczyka i reprezentowaną przez niego doktryną po toczących się kontrowersjach wokół jego osoby, których sam także był przyczyną. Czy rzeczywiście udało mu się całkowicie, bądź też częściowo, odejść od niego na płaszczyźnie interpretacji biblijnej i wynikającej z niej myśli teologicznej?² Odpowiedź na to pytanie będzie negatywna, kiedy weźmiemy pod uwagę teksty Hieronima pisane przed wielką kłótnią z Rufinem z Akwilei i sporami wokół Orygenesa. Można to dostrzec chociażby w komentarzach do Ksiąg proroków Micheasza, Nahuma czy Habakuka powstałych w $393 \mathrm{roku}$, a zatem przed wspomnianymi wydarzeniami. Wówczas bowiem dla Hieronima Orygenes był swoistym „bożyszczem”, o czym nie omieszkał wspomnieć chociażby w prologu do komentarza do Księgi Micheasza: „Nam quod dicunt Origenis me volumina compilare et contaminari non decere scripta veterum, quo illi maledictum vehemens esse existimant, eandem laudem ego maximam duco, cum illum imitari volo quem cunctis prudentibus et vobis placere non dubito"3.

Odpowiedź na postawione wyżej pytanie należy zweryfikować w świetle komentarzy powstałych po sporach wokół Orygenesa. Wydaje się, że ciekawy

1 M. Simonetti, Między dosłownością a alegorią, przekł. T. Skibiński, Kraków 2000, s. 339 .

2 Na temat wpływu Orygenesa na komentatora Hieronima por. S. Wielgus, Badania nad Biblia $w$ starożytności i $w$ średniowieczu, Lublin 1990, s. 60-61.

3 Św. Hieronim, KomMich, PL 25,1189 CD. 
pod tym względem jest komentarz św. Hieronima Do Księgi Jonasza ${ }^{4}$, w którym wyraźnie odwołuje się do nauki Aleksandryjczyka, chociaż nie mówi o nim bezpośrednio. Można jednak się domyślać, że chodzi o Orygenesa, tym bardziej że powołuje się na apokatastazę, która przecież tak mocno była związana $\mathrm{z}$ jego osobą.

Pomimo wspomnianych jasnych i negatywnych aluzji do Orygenesa, dokładna lektura komentarza Do Księgi Jonasza dostarcza wątpliwości, czy rzeczywiście Hieronim całkowicie zerwał z egzegezą Aleksandryjczyka. Postaramy się za pomocą analizowanego tekstu Hieronima odpowiedzieć na postawione pytanie. Należy zaznaczyć, że także Orygenes był autorem komentarza Do Księgi Jonasza, o czym wspomina Hieronim w jednym ze swoich listów kierowanych do Pauli ${ }^{5}$. Do końca jednak nie dowiemy się, na ile i w jakim stopniu to właśnie dzieło Aleksandryjczyka inspirowało naszego autora, ponieważ nie zachowało się do naszych czasów.

\section{Terminologia egzegetyczna Orygenesa u Hieronima}

Pierwsze spostrzeżenie, jakie rodzi się po lekturze komentarza do proroka Jonasza, dotyczy terminologii, którą posługuje się Hieronim. Przyjrzymy się tylko tej, która związana jest z zastosowaną przez naszego autora metodą egzegetyczną. Jeżeli chcielibyśmy zapytać o sposób interpretacji Księgi, należałoby stwierdzić, że rozgranicza w tekście to, co dosłowne (historia, fundamenta historiae, litterae), od tego, co duchowe, przenośne, niekiedy nawet wyraźnie typologiczne. Dlatego też w komentarzu św. Hieronima pojawiają się takie terminy, jak: anagoge, tropologia czy allegoria. Wiadomo, że są to słowa techniczne, których używano przy komentowaniu tekstu biblijnego, chcąc ukazać sens duchowy Pisma Świętego. Należy także zaznaczyć, że wymienione określenia były powszechnie używane przez pisarzy środowiska aleksandryjskiego, zwłaszcza zaś przez Orygenesa. Czy na ich podstawie nie można zatem sądzić, że Hieronim w terminologii egzegetycznej jest $\mathrm{w}$ jakimś stopniu zależny od Aleksandryjczyka i tak naprawdę nie zdystansował się od niego, zwłaszcza gdy chodzi o sposób wyjaśniania Biblii? Aby się o tym przekonać, musimy przyjrzeć się tekstom, w których występują wspomniane terminy.

4 Wydania tekstu: PL 25,1117 B-1152 B; Saint Jérôme, Sur Jonas, introduction, texte latin, traduction et notes de P. Antin, SCh 43, Paris 1956; Święty Hieronim, Komentarz do Księgi Jonasza, wstęp biblijny S. Gądecki, wstęp patrystyczny, przekł., oprac. L. Gładyszewski, ŻMT 8, Kraków 1998. W niniejszym opracowaniu posługuję się wszystkimi wspomnianymi wydaniami tekstu, zarówno łacińskim, francuskim, jak i polskim, i stosuję skrót KomJon z podziałem na księgi i numery podanym przez polskiego tłumacza.

5 Por. Św. Hieronim, Listy, t. I, XXX 4, przekł. i przedmowa J. Czuj, Warszawa 1952, s. 195 . 
Najczęściej pojawia się w komentarzu Hieronima słowo tropologia, bo aż cztery razy, oraz występuje także w formie przysłówkowej jako tropologice. Kiedy nasz autor wyjaśnia powołanie Jonasza, by skierował słowo Pana do mieszkańców Niniwy (por. Jon 1,1-2), stwierdza, że „według tropologii (iuxta tropologiam) Pan, nasz Jonasz, to jest właśnie gołąb lub bolejący. Ten wyraz bowiem może oznaczać jedno i drugie, że mianowicie Duch Święty pod postacią gołębicy zstąpił i w Nim pozostał (por. Mk 1,10; Łk 3,22; J 1,32-33) albo że On bolał nad naszymi ranami i płakał nad Jeruzalem (por. Łk 19,41)"'.

Termin tropologia został tutaj użyty niewątpliwie w sensie duchowym i stosuje się do Chrystusa, szczegółowo zaś do Jego posłannictwa w podwójnym znaczeniu. Jedno dotyczy początku działalności Jezusa, dokładnie zaś chodzi o chrzest w Jordanie i zstąpienie na Niego Ducha Świętego w postaci gołębicy. Drugi natomiast odnosi się już do czasu konkretnego przepowiadania Chrystusa, który płakał nad Jerozolimą, ponieważ nie rozpoznała w Nim Mesjasza, w przyszłości zaś zostanie całkowicie zniszczona. Mamy zatem tutaj do czynienia $\mathrm{z}$ duchowym odczytaniem konkretnego tekstu biblijnego, co więcej, misja Jonasza wśród pogańskiej Niniwy jest postrzegana w kontekście chrystologicznym. Chrystus bowiem doświadczy tego samego, co starotestamentalny prorok: poganie podejmą pokutę, uwierzą w Niego, Izrael zaś pozostanie w złu. Stąd ten „bolejący Jonasz”, jak nazywa Jezusa Hieronim w swoim komentarzu.

Kolejny fragment, w którym pojawia się u Hieronima słowo tropologia, dotyczy tekstu, gdzie nasz komentator wyjaśnia, co oznacza prośba sternika z okrętu skierowana do Jonasza, by ten modlił się do swojego Boga o ocalenie wszystkich przebywających na statku w czasie rozszalałej burzy (por. Jon 1,5b-6). Hieronim komentuje to wydarzenie w następujący sposób: „a zatem według tropologii było tam więcej takich ludzi (iuxta tropologiam plures sunt), którzy razem z Jonaszem podróżowali i choć nie mieli własnych bogów, dążyli również do kontemplowania radości. Lecz gdy los padnie na Jonasza, gdy przez jego śmierć uspokoi się burza świata i cisza znowu zapanuje na morzu, wówczas jeden Bóg zostanie uczczony i złożone zostaną duchowe ofiary"”.

Mamy tutaj do czynienia, podobnie jak w poprzednim fragmencie, $\mathrm{z}$ duchowym odczytaniem tekstu biblijnego. Pobieżna lektura wskazuje na to, że nie ma on charakteru ściśle chrystologicznego, co raczej teologiczny, ponieważ mówi o uwierzeniu w Boga i przyjęciu Go przez pogan za swojego Boga, jeżeli weźmiemy pod uwagę fakt, że współpasażerowie Jonasza na statku reprezentują taką właśnie grupę ludzi. Tego rodzaju wyjaśnienie byłoby jednak niepełne, gdyż należy podkreślić, że dla Hieronima Jonasz $=$ Chrystus. Czy nie należy zatem we wrzuceniu do morza Jonasza dostrzec wyraźnego kontekstu chrystologicznego, czyli ofiary

6 KomJon I 1, s. 89; PL 25, 1120 D.

7 KomJon I 6, s. 98; PL 25, 1125 D. 
Jezusa na drzewie krzyża, Jego śmierci i zmartwychwstania, co w efekcie zaowocowało nawróceniem wielu mieszkańców ziemi? Wydaje się, że Hieronim w takim właśnie kontekście odczytuje to wyrażenie, tym bardziej że sam Chrystus powołuje się w Ewangelii na znak Jonasza w odniesieniu do swojej Osoby, kiedy zapowiada swoją mękę, śmierć i zmartwychwstanie (por. Łk 11,29). Można zatem dostrzec w użytym tutaj terminie tropologia utożsamienie typologiczne (Jonasz-Chrystus).

Inny jeszcze tekst, gdzie pojawia się termin tropologia, dotyczy wyjaśnienia fragmentu, w którym Jonasz boleje przed Bogiem, a nawet na Niego się obraża, że Ten spowodował uschnięcie bluszczu, pod którym schronił się prorok w czasie upału i zimna (por. Jon 4,10-11). Hieronim od razu przechodzi do duchowej interpretacji, chociaż stwierdza, że nie należy ona do łatwych. „Niezwykle wielka to trudność wyjaśnić - pisze nasz autor - jak na zasadzie tropologii do Syna (iuxta tropologiam dicatur ad filium) odnoszą się słowa: «Ty bolejesz nad bluszczem, przy którym nie pracowałeś i którego nie pielęgnowałeś, aby wzrastał, skoro wszystko stało się przez Niego a nic się nie stało bez Niego" $(\mathrm{J} 1,3)^{\text {”. }}$.W dalszej części tego tekstu Hieronim powołuje się na „kogoś”, kto zdanie Chrystusa z Ewangelii św. Marka: „Nikt nie jest dobry, jak tylko jeden Bóg” $(10,18)$, wyjaśniał w sposób bluźnierczy, ponieważ dokonał porównania dobrego Boga z Nowego Testamentu z Synem, którego umieścił na niższym stopniu i zarzuca mu popadnięcie w herezję Marcjona9 . Czy w pierwszym rzędzie Hieronim myślał tutaj o Orygenesie i głoszonym przez niego subordynacjonizmie? ${ }^{10}$ Można wysnuć tego rodzaju wniosek, tym bardziej że Hieronim nie zgadzał się z takim przedstawieniem Syna przez Aleksandryjczyka, o czym przekonamy się w następnym punkcie tego opracowania. Autor komentarza Do Księgi Jonasza jest bardzo surowy w swojej ocenie, skoro subordynacjonizm reprezentowany przez większość teologów przednicejskich określa jako herezję i stawia na tej samej płaszczyźnie co doktrynę Marcjona o „dwóch bogach”. Nie można zgodzić się tutaj z Hieronimem, ponieważ nauka wspomnianego gnostyka całkowicie różniła się od subordynacjonizmu, który, przynajmniej w wydaniu Orygenesa, nie odbierał ani prawdziwego bóstwa, ani też człowieczeństwa Chrystusowi, tylko stawiał nieco „niżej” Jego Osobę w odniesieniu do Ojca ${ }^{11}$. Użyty tutaj zatem termin tropologia ma ponownie zabarwienie chrystologiczne i określa, według niego, sens

8 KomJon IV 10, s. 139; PL 25, 1150 C.

9 Por. tamże.

10 Do takiego samego wniosku dochodzi J.N.D. Kelly w swojej monografii: Hieronim. Życie, pisma, spory, przekł. R. Wiśniewski, Warszawa 2003, przypis 37, s. 434.

11 Z drugiej strony, Hieronim wspomina w tym kontekście postać Ariusza, o którym wyraża się bardziej pochlebnie i z większym zrozumieniem niż o Marcjonie: Ariusz „głosił wprawdzie, że Ojciec jest większy, a Syn mniejszy, nie zaprzeczał jednak temu, że Syn jest stwórcą" (KomJon IV 10, s. 140; PL 25, 1150 C). 
duchowy wspomnianego tekstu proroka Jonasza. Można również zauważyć, iż jest on także synonimem typologii.

Ostatni raz, kiedy Hieronim stosuje w tekście komentarza termin tropologia, używa go w podwójnej formie, mianowicie rzeczownikowej (tropologia) i przysłówkowej (tropologice). Kontekst stanowi tutaj fragment Listu do Galatów św. Pawła, kiedy jest mowa o Hagar i Sarze, które reprezentują dwa Testamenty (por. Ga 4,22-31). Autor komentarza poucza, że „roztropnego czytelnika należy poprosić, by nie oczekiwał zachowania tego samego porządku dla tropologii (ordinem tropologiae) i dla historii. Apostoł wprawdzie odnosi Agar i Sarę do dwóch Testamentów (Ga 4,22-31), a jednak nie wszystko, o czym opowiada historia, możemy objaśnić tropologicznie (tropologice interpretari possumus)"12.

Tego typu zastrzeżenie ze strony św. Hieronima świadczy o tym, że wyjaśnienie duchowe tekstu biblijnego obwarowuje pewnymi zastrzeżeniami. Nie można, według niego, wszędzie stosować tropologii, ale należy czynić to z uwagą, wiedzą, nawet roztropnością, ponieważ nie wszystkie miejsca Księgi Jonasza pozwalają na to komentatorowi.

Święty Hieronim używa także raz słowa anagoge, kiedy objaśnia zdanie z Księgi Jonasza mówiące o wrzuceniu proroka do morza. Autor komentarza pisze: „Według anagogii zaś (iuxta anagogen) przebywanie w sercu morza oznacza, że znajduje się wśród doświadczeń. A jednak chociaż znajdował się między gorzkimi wodami i doświadczany był pod każdym względem prócz grzechu, nie doznał goryczy tych wód"13. Komentator używa terminu iuxta anagogen, aby określić w ten sposób sens duchowy interpretowanego tekstu. Wchodzi tutaj $\mathrm{w}$ typologię (Jonasz-Chrystus) wypełnioną wyraźną alegorią. Słowo anagoge pojawia się także w innych dziełach św. Hieronima, np. w komentarzu Do proroka Sofoniasza, gdzie pisze m.in.: „hucusque historiae sensus [...] videamus et anagogen"14. Hieronim podkreśla znaczenie dwóch sensów obecnych w tekście biblijnym: sens historyczny, którego nie można, jego zdaniem, pominąć, oraz duchowy, oznaczony przez niego terminem anagoge.

Pozostał jeszcze jeden techniczny termin, jakim posługuje się Hieronim $\mathrm{w}$ duchowej egzegezie tekstu proroka Jonasza, mianowicie dobrze znany i często używany, zwłaszcza przez aleksandryjczyków, allegoria. Pojawia się on w kontekście historii wędrówki Narodu Wybranego do Ziemi Obiecanej, konkretnie zaś odnosi go do wydarzenia, kiedy Mojżesz uderzył w skałę, by wypłynęła z niej woda (por. Wj 17,6; Lb 20,11). W związku z tym Hieronim pyta czytelnika, „,czy całą historię tego miejsca podciągniemy pod zasadę alegorii (sub lege allegoriae)? Czy raczej każde miejsce według odrębnej historii otrzyma odrębne duchowe

\footnotetext{
12 KomJon I 3, s. 94; PL 25, 1123 C.

13 KomJon II 4, s. 111; PL 25, 1133 B.

14 Św. Hieronim, KomSof 1,4; PL 25, 1343 C.
} 
znaczenie? Jak więc te świadectwa mają własne wyjaśnienia i jak ani wydarzenia poprzedzające, ani następujące nie wymagają tej samej alegorii (allegoriam), tak również prorok Jonasz bez pewnego niebezpieczeństwa dla interpretatora $\mathrm{w}$ całości nie będzie mógł być odniesiony do Pana"15.

Hieronim jest świadomy tego, że metoda alegoryczna wymaga pewnej racjonalizacji, to znaczy nie każdy tekst wolno lub też można według niej interpretować. Podobne stwierdzenie znajdziemy u Orygenesa, który był wielkim zwolennikiem i propagatorem alegorezy, ale zawsze tam, gdzie wydawało mu się to konieczne. Hieronim uważa, że porównywać Jonasza z Chrystusem wolno tylko wówczas, kiedy znajdzie to swoje potwierdzenie w wydarzeniach ewangelicznych. Oznacza to, że jeżeli osoba Jonasza i związane z nim wydarzenia zostały zrealizowane w Osobie Chrystusa, na zasadzie: zapowiedź-znak, zapowiedź-spełnienie, tylko wówczas można posługiwać się metodą alegoryczną. Należy jednak zaznaczyć, że w tym przypadku istnieje bliska granica alegorii $\mathrm{z}$ typologią, niemalże niezauważalna.

W związku z analizowanymi terminami egzegetycznymi, które występują w komentarzu Hieronima Do Księgi Jonasza, należy w tym miejscu omówić krótko interpretację Pisma Świętego u Orygenesa. Nie jest to zadanie łatwe, wielu badaczy próbowało bowiem to uczynić z większym lub mniejszym powodzeniem. Można jednak pokusić się, idąc za tropem wielkiego znawcy Orygenesa H. Crouzela ${ }^{16}$, o przedstawienie niektórych klasyfikacji związanych z egzegezą Aleksandryjczyka. Z całą pewnością najbardziej popularny podział znaczenia Pisma Świętego opiera się na trychotomicznej antropologii Orygenesa, którą zawarł w dziele $O$ zasadach $^{17}$. Sens dosłowny odpowiada ciału, sens moralny dotyczy życia na tym świecie i odnosi się do duszy, sens mistyczny natomiast związany jest $\mathrm{z}$ duchem i tym samym przekracza wymiar ziemski życia człowieka. Aleksandryjczyk w ogóle nie wyjaśnia wspomnianych trzech znaczeń, ale od znaczenia dosłownego przechodzi do moralnego lub też mistycznego ${ }^{18}$.

Warto przyjrzeć się jeszcze jednej klasyfikacji związanej z egzegezą Orygenesa, którą proponuje H. de Lubac ${ }^{19}$. Wskazuje on mianowicie na cztery znaczenia Pisma Świętego. Pierwsze to oczywiście dosłowne. Drugie nazywa alegorycznym, ono też potwierdza fakt, że Chrystus stanowi klucz do całego Starego Testamentu i mamy tutaj do czynienia z chrystocentryczną interpretacją tekstu biblijnego.

15 KomJon I 3, s. 95; PL 25, 1124 A.

16 Por. H. Crouzel, Orygenes, przekł. J. Margański, Bydgoszcz 1996. Jest to monografia w całości poświęcona temu wielkiemu egzegecie i teologowi. Dla interesującego nas tematu na uwagę zasługuje zwłaszcza druga część zatytułowana: Egzegeta, s. 97-128.

17 Por. Orygenes, O zasadach, przekł. i oprac. S. Kalinkowski, ŹMT 1, Kraków 1996, zwłaszcza księga IV, 2,4-6, s. 339-343.

18 Por. H. Crouzel, dz. cyt., s. 121-122.

19 Por. H. de Lubac, Exégèse Médiévale, I/1, Paris 1959, s. 198-219. 
Zastosowanie alegorii pozwala na przejście od Starego do Nowego Testamentu rozumiane jako egzegeza duchowa. Dalej następuje znaczenie moralne albo też tropologiczne i związane jest z życiem moralnym chrześcijanina pomiędzy dwoma nadejściami Chrystusa. Tropologia odnosi się zatem do Chrystusa i chrześcijanina w rozumieniu doczesnym. Mamy tutaj do czynienia z duchową egzegezą Nowego Testamentu. Czwarte i ostatnie znaczenie nazywa de Lubac anagogicznym, ponieważ daje ono przedsmak rzeczywistości eschatologicznej. Inaczej mówiąc, chodzi tutaj o rolę profetyczną Pisma Świętego, czyli proroctwo uobecnia to, co zostało już przepowiedziane. O znaczeniu anagogicznym można powiedzieć, że sytuuje się na styku Ewangelii doczesnej i Ewangelii wiecznej. Należy jeszcze dodać, że zarówno znaczenie tropologiczne, jak i anagogiczne można odnaleźć także w Starym Testamencie, skoro alegoria przekształciła go w Nowy Testament ${ }^{20}$.

Czy z przedstawionej krótkiej klasyfikacji nie narzuca się wyraźne podobieństwo pojmowania egzegezy u Orygenesa i Hieronima? Wydaje się, że autor komentarza Do Księgi Jonasza, chociaż pragnął odejść od swojego kiedyś mistrza, nie do końca mu się to udało. U Hieronima nie ma, co prawda, systematycznego podziału na trzy znaczenia Pisma Świętego, jak u Orygenesa (dosłowne, moralne i mistyczne), bądź też na cztery (dosłowne, alegoryczne, moralne, mistyczne). Niejednokrotnie stwierdza jednak, że prawda historyczna (historia veritas) zawarta w słowie Bożym zostaje wyjaśniona zazwyczaj przez tropologię i metaforę ${ }^{21}$. Jeszcze dobitniej mówi o tym w jednym ze swoich listów napisanym ok. 407 roku do Hedybii, a zatem już wówczas, kiedy stał się zagorzałym przeciwnikiem Orygenesa. Hieronim pisze, że „W historii zachowuje się kolejność tego, co jest napisane; w przenośni od znaczenia dosłownego wznosimy się do głębszego i cokolwiek u poprzedniego narodu dokonało się cieleśnie, tłumaczymy w sensie moralnym i obracamy na pożytek naszej duszy"22.

Wspomniane podobieństwo można dostrzec $\mathrm{w}$ analizowanych tekstach Hieronima. Ogranicza on raczej termin tropologia do Starego Testamentu, chociaż zdarza się także, iż posługuje się nim w odniesieniu do Nowego, zwłaszcza wówczas, kiedy wyprowadza etymologię poszczególnych słów i stosuje go do Chrystusa, Maryi, Kościoła, heretyków czy też sądu ostatecznego ${ }^{23}$.

Analizowane terminy nie mają też u Hieronima jakiegoś jednoznacznego sensu, który wskazywałby na narzędzia pracy metodycznej. Allegoria stanowi dla Hieronima rozumienie duchowe (intelligentia spiritalis), tropologia służy

20 Por. tamże.

21 Por. Św. Hieronim, In Osee 10,11; PL 25, 909 B.

22 Św. Hieronim, Listy, CXX 12, t. III, przekł. i przedmowa J. Czuj, Warszawa 1952, s. 150 .

23 Por. P. Antin, Introduction, w: Saint Jérôme, Sur Jonas, SCh 43, Paris 1956, s. 25, przyp. 1. 
przechodzeniu od prawdy historycznej (historiae veritatis) do wiary proroczej (prophetiae fides) i oznacza sens typologiczny, anagoge to sens wyższy od dosłownego, który wyraża także sens duchowy tekstu biblijnego. Wszystkie one znajdują swoje źródło w środowisku aleksandryjskim, zwłaszcza zaś u Orygenesa ${ }^{24}$. Przypomnijmy, że u Aleksandryjczyka mamy także do czynienia ze znaczeniem dosłownym, dalej - z alegorycznym, czyli duchowym (u Hieronima - allegoria), następnie z tropologicznym (u Hieronima - tropologia), dotyczącym Ewangelii doczesnej, ale także wydarzeń ze Starego Testamentu, które alegoria przekształciła w Nowy. Znaczenie anagogiczne (u Hieronima - anagogia) natomiast związane jest $\mathrm{z}$ eschatologicznym pojmowaniem tekstu biblijnego.

\section{Próby interpretacji chrystologicznej w duchu Orygenesa}

Drugi element związany z Orygenesem, jaki można zauważyć u Hieronima, dotyczy fragmentów, które zostały niemalże dokładnie tak samo zinterpretowane jak u Aleksandryjczyka. Chodzi tutaj o tekst Jonasza mówiący o jego ucieczce od Pana do Tarszisz (por. Jon 1,3a). Hieronim wyjaśnia to wydarzenie w duchu chrystologicznym, ponieważ stwierdza, że „o naszym Panu i Zbawicielu możemy również powiedzieć, że opuścił swój dom i ojczyznę, a przyjmując ciało $\mathrm{w}$ jakiś sposób uciekł z niebios i przybył do Tarszisz, to znaczy na morze doczesności”25.

Z całą pewnością można powiedzieć, że jest to bardzo śmiała interpretacja tego wydarzenia ${ }^{26}$ po linii chrystologicznej i dodatkowo jeszcze - samego Orygenesa. Ten bowiem w Homiliach o Księdze Jeremiasza wyjaśnia tekst „Opuściłem swój dom, pozostawiłem swoje dziedzictwo” (Jr 12,7) w taki sam sposób. Uważa, że mowa jest tutaj o Chrystusie, który opuszcza Ojca i niebo, przybywa na ziemię, przyjmuje postać człowieka, aby zbawić świat ${ }^{27}$.

Podobną interpretację spotykamy także w ostatniej księdze Hieronimowego komentarza Do Księgi Jonasza, kiedy jest mowa o modlitwie proroka, który prosi Boga, by Ten zabrał jego duszę (por. Jon 4,2-3). Hieronim zwraca uwage na to, że Jonasz odczuwał smutek i skarżył się Bogu z powodu tego, że nie mógł ocalić ludu izraelskiego. Interpretuje to w duchu chrystologicznym, wskazując na Chrystusa, który wobec trudności głoszenia Boga dobrego i sprawiedliwego

$24 \mathrm{Na}$ temat egzegezy Hieronima por. P. Jay, Jérôme et la pratique de l'exégèse, w: Le monde latin antique et la Bible, sous la direction de J. Fontaine, Ch. Pietri, Paris 1985, s. 523-541.

25 KomJon I 3; PL 25, 1122 BC.

26 Tak nazywa tę interpretację M. Simonetti, dz. cyt., s. 338.

27 Por. Orygenes, Homilie o Księdze Jeremiasza 10,7, przekł. i oprac. S. Kalinkowski, PSP 30, Warszawa 1983, s. 90-91. 
wolał opuścić swój dom, całe dziedzictwo i łono Ojca ${ }^{28}$. Mamy tutaj do czynienia $\mathrm{z}$ wyraźnym antygnostyckim charakterem tego tekstu, który u Orygenesa otrzymuje także kontekst chrystologiczny, ale o wiele bardziej rozwinięty niż u Hieronima ${ }^{29}$.

Wymienione przykłady ponownie ilustrują pewną zależność św. Hieronima od Orygenesa, tym razem nie tylko na płaszczyźnie zastosowania słownictwa i metody egzegetycznej, ale także odczytywania konkretnych tekstów w takim samym duchu chrystologicznym. Prawdopodobnie, gdybyśmy posiadali komentarz Orygenesa Do Księgi Jonasza, można by wskazać na wiele więcej takich miejsc, co staje się całkowicie zrozumiałe, kiedy weźmiemy pod uwagę zachwyt Hieronima względem Aleksandryjczyka, którego doktryna pozostała w niektórych jego dziełach, pomimo późniejszego odrzucenia, przynajmniej w deklaracjach słownych.

\section{Ocena apokatastazy przez Hieronima}

Pozostał jeszcze jeden ciekawy temat $\mathrm{w}$ analizowanym komentarzu związany z Orygenesem, mianowicie problem apokatastazy. Znalazł on swoje miejsce także w kilku wypowiedziach Hieronima. Przytoczę tylko ważniejsze ich fragmenty. Kontekst biblijny dotyczy króla Niniwy, który pod wpływem nawoływania Jonasza nawrócił się (por. Jon 3,6-9). Hieronim komentuje to wydarzenie w następujący sposób:

Wiem, że nader wielu interpretuje króla Niniwy - on to jako ostatni usłyszał przepowiadanie, zszedł ze swego tronu, odrzucił dawny ozdobny strój i przyodziany w wór siadł na popiele, i nie ograniczając się do własnego nawrócenia innym również razem ze swoimi wodzami zalecił pokutę mówiąc: Ludzie i zwierzęta, i woły, i trzody niech się umartwią głodem, niech się przyodzieją w wory, a potępiwszy dawne występki niech wszyscy nastawią się na pokutę - że nader wielu upatruje w nim, [królu Niniwy], diabła, który pod koniec świata - ponieważ żadne rozumne i przez Boga uczynione stworzenie nie miałoby zginąć - porzucając swoją pychę ma jakoby czynić pokutę i na dawne miejsce powrócićs ${ }^{30}$.

Spróbujmy skomentować ten tekst ze szczególnym uwzględnieniem niektórych wyrażeń, które sugerują wyraźną niechęć Hieronima do Orygenesa za jego poglądy o powszechnym zmartwychwstaniu. Najpierw wyrażenie scio plerosque. Tłumacz polskiego przekładu zaproponował „nader wielu”, ale w przypisie stwierdził także, iż Hieronim chciał chyba raczej powiedzieć, że „niektórzy” takiego

30 KomJon III 9, s. 126; PL 25, 1141 C.
} 
są zdania ${ }^{31}$. Przekład francuski używa „certains" ${ }^{\text {"2 }}$, co można przetłumaczyć jako: „niektórzy”. Niezależnie od proponowanych przez tłumaczy przekładów wspomnianego wyrażenia należy podkreślić, że kryje się w nim osoba Orygenesa oraz jego zwolenników współczesnych Hieronimowi, prawdopodobnie także chodzi o Rufina z Akwilei. Mamy tutaj zatem początek wyraźnego ataku na doktrynę Aleksandryjczyka o apokatastazie. Przybiera ona na sile w dalszej partii zacytowanej wypowiedzi Hieronima. W królu Niniwy dostrzega on diabła, powołując się, iż plerosque tak uważa.

Potępienie apokatastazy następuje u św. Hieronima w końcowej wypowiedzi przytoczonego fragmentu komentarza do proroka Jonasza, a także w dalszych jeszcze tekstach. Nasz interpretator zarzuca, że tego rodzaju postawa, to znaczy wiara w zbawienie szatana, bierze się z niewłaściwego rozumienia Księgi Daniela, gdzie jest mowa o tym, że Nabuchodonozor odbył siedmioletnią pokutę i powrócił do dawnego królestwa (por. Dn 4,24. 29. 33) 33. Co więcej, wiarę w zbawienie szatana po odbyciu odpowiedniej pokuty uważa za zbyt łatwe popadnięcie w występki (ad vitia putantes), ponieważ Pismo Święte wyraźnie mówi o istnieniu grzeszników wrzuconych w ogień wieczny przygotowany dla diabła i jego aniołów. Dla jeszcze lepszego zilustrowania swojego oburzenia na tego typu doktrynę Hieronim powołuje się na Boże miłosierdzie względem grzeszników, ale z drugiej strony zaprzecza, że może nastąpić odrodzenie wszystkich rzeczy i uzyskanie dla wszystkich tej samej godności. Kłóci się to bowiem z logiką, która pyta: „jaka wówczas będzie różnica między dziewicą a prostytutką? Jaka różnica między Matką Pana a ofiarami - nawet mówić o tym jest przestępstwem - publicznych rozkoszy? Czy tym samym będzie Gabriel i diabeł? Tym samym apostołowie i demony? Tym samym prorocy prawdziwi i fałszywi? Tym samym męczennicy i prześladowcy?"34.

Należy zaznaczyć, że nie tylko w komentarzu Do Księgi Jonasza występuje Hieronim przeciwko apokatastazie Orygenesa, czyni to wielokrotnie przy nadarzających się okazjach egzegetycznych ${ }^{35}$. Pełne oburzenia odrzucenie apokatastazy świadczy niewątpliwie o tym, że prawdopodobnie Hieronim czerpał obficie z Orygenesa ${ }^{36}$. Od starożytności trwa dyskusja, czy Orygenes rzeczywiście wierzył w zbawienie szatana. Zagorzali przeciwnicy Aleksandryjczyka - Rufin z Akwilei i Hieronim - których właśnie poróżnił orygenizm, zajęli w tej kwestii

31 Por. KomJon, przypis 18, s. 126.

32 Por. tekst francuski w SCh 43, s. 97. W przyp. 2 tłumacz podaje jeszcze inne propozycje wcześniejszych przekładów.

33 Por. KomJon III 9, s. 126-127; PL 25, 1142 A.

34 KomJon III 9, s. 127; PL 25, 1142 B.

35 Por. H. Crouzel, L'Hadès et la Géhenne chez Origène, Gregorianum 59 (1978), s. 291-329.

36 Por. J.N.D. Kelly, dz. cyt., s. 254. 
całkowicie przeciwne stanowiska. Na podstawie tego samego listu Orygenesa Rufin z Akwilei podważa ten zarzut, co więcej, oskarża przeciwników ${ }^{37}$, podczas gdy Hieronim, cytując obszerniejszy fragment zarzut potwierdza ${ }^{38}$. Jednakże $\mathrm{w}$ Apologia contra Hieronymum ${ }^{39}$ Rufin nie wypowiedział się tak zdecydowanie jak poprzednio, ale pozostawił Orygenesowi troskę o to, by zdał przed Bogiem sprawę ze swoich myśli. Nie ulega wątpliwości, że Orygenes jako hipotezę głosił pogląd o ostatecznym zbawieniu szatana, co zresztą mieściło się w logice jego systemu. Należy jednak podkreślić, że nigdy nie była to doktryna Orygenesa, ale teoria, którą wyprowadzał z Pisma Świętego, chociażby bazując na tekstach mówiących o Bożym miłosierdziu ${ }^{40}$.

W konkluzji nasuwa się wyraźny wniosek, że św. Hieronim ciągle korzystał z egzegezy i myśli Orygenesa, jeszcze po deklaracji zerwania z jego doktryną, na trzech płaszczyznach. Pierwszą można nazwać metodą interpretacji tekstu biblijnego, gdzie stosuje niektóre zasady Aleksandryjczyka w odniesieniu do sposobu komentowania Pisma Świętego. Nie oznacza to oczywiście reguły, można mówić jedynie o pewnych bardzo podobnych elementach egzegezy Orygenesa, które znalazły się w analizowanym komentarzu Hieronima. Druga płaszczyzna jest związana z pierwszą i dotyczy chrystologicznego odczytywania niektórych fragmentów z Pisma Świętego w duchu orygenesowskim. Trzecia natomiast to apokatastaza, od której całkowicie się odcina nasz autor i zdecydowanie ją potępia. Stanowi ona jednak przedmiot jego zainteresowania, skoro poświęcił jej nieco uwagi w swoim komentarzu Do Ksiegi Jonasza.

37 Por. Rufin, De adulteratione librorum Origenis 7.

38 Por. Św. Hieronim, Apologia przeciw Rufinowi 2, 18, przekł. pol. S. Ryznar, PSP 51, Warszawa 1989, s. 75-78.

39 Por. Rufin, Apologia contra Hieronymum 1, 10.

$40 \mathrm{Na}$ temat apokatastazy u Orygenesa napisano stosunkowo dużo artykułów, por. chociażby jeden z rozdziałów w cytowanej monografii H. Crouzela, Orygenes, s. 341-352; albo H. Pietras, Apokatastaza według Ojców Kościoła, CT 62 (1992), fasc. III, 21-41. 


\section{Les éléments de l'exégèse at de la doctrine d'Origène dans le commentaire du Livre de Jonas de saint Jérôme}

\section{Résumé}

Après l'apparition de certains conflits envers Saint Jérôme, nous nous posons la question: est-ce que Saint Jérôme réussissait à s'écarter partiellement ou totalement d'Origène au niveau de l'inteprétation biblique et de la réflexion née de celle-ci ? Dans ce présent article j’essaie de donner la réponse à cette question à la lumière du commentaire de Saint Jérôme concernant le Livre de Jonas. Dans la conclusion, nous nous remarquons que Saint Jérôme puisait sans cesse de l'exégèse et de la pensée d'Origène aux trois niveaux, même après la déclaration de vouloir rompre avec sa doctrine. En ce qui concerne les trois niveaux, nous pouvons appeler le premier niveau - la méthode d'interprétation $\mathrm{du}$ texte biblique où il emprunte certains styles d'Origène relativement aux analyses de la Bible. Le deuxième niveau est lié au premier et concerne la lecture christologique de certains passages de la Bible. Celui-ci est rédigé dans l'esprit d'Origène. Le troisième niveau consitue l'apokatastasis. L'auteur néglige fortement ce-dernier et de plus il le critique. Néanmoins, nous nous remarquons certain intérêt de l'auteur envers le dernier niveau. Saint Jérôme analyse le troisième niveau dans le commentaire du Livre de Jonas. 